\title{
PENGARUH KEBIJAKAN BESARNYA DIVIDEN TERHADAP HARGA SAHAM PERUSAHAAN
}

\author{
Phan Krishandani \\ Program Studi Magister Manajemen Universitas Tarumanagara \\ krishandani.p@gmail.com \\ Ignatius Roni Setyawan \\ Program Studi Magister Manajemen Universitas Tarumanagara
}

\begin{abstract}
The purpose of this study was to determine the effect of policy on the amount of dividends on the stock price of companies listed on the Indonesian stock exchange. The determinants tested in this study are dividend policy. the object in this study is the stock price of the companies incorporated in LQ - 45 for the period 2006 to 2008. Subjects in this study are companies incorporated in LQ - 45 engaged in the financial industry, there are 10 companies in 2006 to 2008 that meet the criteria used as a sample. The data used is secondary data collected from the company's financial statements. the method used in this research is analytical descriptive method, to describe data, facts, traits and relationships that occur systematically, factually and accurately. The results of this study indicate that the dividend policy has a significant effect on the company's stock price of $78.2 \%$, while the rest is influenced by other variables.
\end{abstract}

Abstrak : Tujuan dari penelitian ini adalah untuk mengetahui pengaruh kebijakan terhadap jumlah dividen terhadap harga saham perusahaan yang terdaftar di bursa efek Indonesia. Faktor penentu yang diuji dalam penelitian ini adalah kebijakan dividen. objek dalam penelitian ini adalah harga saham perusahaan yang tergabung dalam LQ - 45 untuk periode 2006 hingga 2008. Subjek dalam penelitian ini adalah perusahaan yang tergabung dalam LQ 45 yang bergerak di industri keuangan, terdapat 10 perusahaan pada tahun 2006 hingga 2008 yang memenuhi kriteria yang digunakan sebagai sampel. Data yang digunakan adalah data sekunder yang dikumpulkan dari laporan keuangan perusahaan. Metode yang digunakan dalam penelitian ini adalah metode deskriptif analitis, untuk menggambarkan data, fakta, sifat dan hubungan yang terjadi secara sistematis, faktual dan akurat. Hasil penelitian ini menunjukkan bahwa kebijakan dividen berpengaruh signifikan terhadap harga saham perusahaan sebesar 78,2\%, sedangkan sisanya dipengaruhi oleh variabel lain.

Keywords: Dividend, Stock Price, Dividend Policy, Dividend Payout Ratio

\section{PENDAHULUAN}

Dengan adanya perkembangan teknologi informasi calon investor akan dimudahkan untuk mencari informasi-informasi yang terkait dan dengan informasi ini calon investor dengan mudah dapat mengambil keputusan penting dalam berinvestasi. manajer perusahaan selain memperhatikan laba perusahaan, juga harus memperhatikan keuntungan yang diterima investor. Keuntungan yang diterima investor biasanya ada dua macam, yaitu laba modal (capital gain) dan dividen. Oleh karena harga saham berubah setiap saat, maka laba modal tidak dapat ditentukan secara pasti, sedangkan jumlah dividen ditentukan oleh rapat dewan direksi perusahaan sehinga jumlahnya dapat ditentukan sesuai keputusan kebijakan dividen perusahaan. Secara umum, keputusan keuangan yang dibuat perusahaan ada dua macam yaitu keputusan investasi dan keputusan pembiayaan. Keputusan investasi menentukan ukuran dan komposisi aset perusahaan sedangkan keputusan pembiayaan menentukan 
struktur utang dan ekuitas perusahaan. Didalam keputusan pembiayaan inilah terkandung keputusan mengenai dividen. Keputusan mengenai dividen ditentukan oleh kebijakan dividen perusahaan, biasanya keputusan ini juga akan mempengaruhi tingkat laba ditahan perusahaan. Karena keputusan ini memiliki dampak yang cukup besar terhadap investor dan perusahaan, maka manajemen perusahaan harus dapat mengembangkan kebijakan dividen agar dapat memuaskan investor dengan pembagian keuntungan dan memaksimalkan kekayaan perusahaan yang tercermin dari harga saham perusahaan.

Tujuan penelitian ini adalah untuk mengetahui pengaruh kebijakan besarnya dividen terhadap harga saham perusahaan, dan untuk mengambarkan data-data, fakta-fakta, sifat-sifat serta hubungan yang terjadi secara sistematis, faktual dan akurat.Variabel dependen pada penelitian ini adalah harga saham, dan variabel independen adalah besarnya dividen.

\section{KERANGKA TEORITIS DAN PENGEMBANGAN HIPOTESIS}

\section{Dividen}

Dividen menurut Weygandt, Keyso, dan Kimmel (2002:602) merupakan pendistribusian laba oleh perusahaan kepada seluruh pemegang saham secara proporsional. jumlah dividen yang dibagikan bisa dihitung dengan dua cara, yaitu sebagai persentase par/ statted value dari saham atau jumlah (amount) tertentu untuk setiap lembar sahamnya.

\section{Pertimbangan Dalam Penghitungan Dividen}

Pertimbangan dalam Penghitungan Dividen menurut Weygandt, Keyso, dan Kimmel (2002:738) Dalam memutuskan jumlahnya, pertimbangan utama yang perlu diperhatikan adalah tersedianya uang tunai di perusahaan, sangat sedikit perusahaan yang membagikan jumlah dividen sebesar jumlah laba ditahannya (retained earnings).

\section{Dividend Irrelevance Theory}

Dividend Irrelevance Theory menurut Miller dan Modigliani (1961) kebijakan dividen tidak mempunyai pengaruh terhadap harga saham, tetapi nilai perusahaan ditentukan oleh resiko bisnis dan kemampuannya dalam menghasilkan laba.

\section{Dividend Catering Theory}

Dividend Catering Theory merupakan teori baru yang diajukan oleh Baker \& Wurgler (2004) Teori ini berpendapat bahwa permintaan investor atas saham yang membayarkan dividen adalah bervariasi sepenjang waktu, karenanya menyebabkan harga relatif perusahaan yang membayar dividen dan yang tidak membayar dividen berfluktuasi.

\section{Jenis Kebijakan Dividen}

Menurut Naveli (1989) ada 3 jenis kebijakan dividen yaitu Constant Dividend Payout Ratio, Stable Per Share Dividend, Reguler Dividend Plus Extra.

\section{Common stock}

Menurut Lawrence J.Gitman (1994:39) : "Common stock are unit of ownership interest or equity, in a corporation". saham dapat didefinisikan sebagai tanda penyertaan atau kepemilikan seseorang atau badan dalam suatu perusahaan. Bentuk saham adalah selembar kertas yang menerangkan bahwa pemilik kertas tersebut adalah pemilik perusahaan yang menerbitkan kertas tersebut 


\section{HIPOTESIS}

Berdasarkan literatur di atas, penelitian ini ingin mengajukan beberapa hipotesis sebagai berikut:

$\mathrm{H}_{0}: \mathrm{b}=0$ (kebijakan dividen tidak berpengaruh terhadap harga saham)

$\mathrm{H}_{1}: \mathrm{b} \neq 0$ (kebijakan dividen berpengaruh terhadap harga saham)

\section{KERANGKA PENELITIAN}

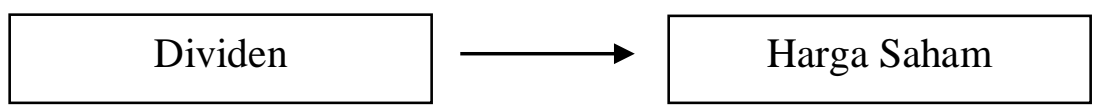

\section{METODE PENELITIAN}

Teknik analisa data yang digunakan pada penelitian ini adalah teknik analisa regresi sederhana. Persamaan regresi sederhana yang diintepretasikan dalam penelitian ini adalah:

$$
\begin{array}{llll}
\cline { 3 - 4 } & \multicolumn{2}{c|}{\mathrm{Y}=\alpha+\mathrm{bX}+\mathrm{c}} & \\
\mathrm{Y} & =\text { harga saham } & \mathrm{X} & =\text { jumlah dividen } \\
\alpha & =\text { koefisien / konstanta } & \mathrm{c} & =\text { koefisien eror } \\
\mathrm{b} & =\text { intercept } & &
\end{array}
$$

Analisis korelasi sederhana digunakan untuk mencari hubungan antara dua variabel, Rumus korelasi yang dipakai dalam penelitian ini ialah korelasi pearson.

$$
\mathrm{r}=\frac{n \sum X Y-\left(\sum X\right)\left(\sum Y\right)}{\sqrt{\left\{n \sum X^{2}-\left(\sum X\right)^{2}\right\}\left\{n \sum Y^{2}-\left(\sum Y\right)^{2}\right\}}}
$$

Nilai koefisien korelasi berkisar antara : $-1 \leq \mathrm{r} \leq 1$, jika $\mathrm{r}=0$, menunjukan bahwa tidak terdapat hubungan antara $\mathrm{X}$ dan $\mathrm{Y}$ $\mathrm{r}>0$, menunjukan bahwa antara kedua variabel tersebut terdapat hubungan yang positif atau bergerak searah, dimana jika X meningkat, maka Y juga akan meningka $\mathrm{r}<0$, menunjukan bahwa antara kedua variabel terdapat hubungan negatif atau tidak searah, dimana jika X meningkat, maka Y menurun

Penilaian sederhana nilai koefisien korelasi, Absolute value of correlative coefficien interpretation
$0,90-1,00 \quad$ Very high correlation
0,70-0,89 High correlation
0,40-0,69 Moderate correlation
0,20-0,39 Low correlation
$0,00-0,19 \quad$ Very low correlation

Uji Paired sample $t$ test dilakukan untuk melihat dua pengukuran pada subjek yang sama terhadap suatu pengaruh dan perlakuan tertentu. perlakuan adalah pengumuman dividen sedangkan data yang berpasangan adalah harga saham sebelum dan sesudah tanggal pengumuman dividen.

Semua teknik analisis dilakukan dengan bantuan program pengolahan statistik Statistical Product and Services Solutions (SPSS). 


\section{PEMILIHAN SAMPEL DAN PENGUMPULAN DATA}

Populasi dari penelitian ini adalah seluruh perusahaan yang tergabung kedalam LQ 45 di bidang keuangan yang terdaftar di Bursa Efek Indonesia (BEI) dan periode penelitiannya adalah 2006-2008. Data yang diperoleh adalah data sekunder. Sampel yang digunakan sebanyak 10 perusahaan keuangan yang dipilih dengan menggunakan metode purposive sampling, di mana sampel yang diambil dari populasi harus memenuhi kriteria tertentu, yaitu merupakan perusahaan keuangan yang terdaftar di Bursa Efek Indonesia selama tahun 2006-2008, mempublikasikan laporan keuangan dalam mata uang Rupiah selama tahun 2006-2008, perusahaan memperoleh laba dari tahun 2006-2008, membagikan dividen dari tahun 2006-2008, dan mendapatkan data harga saham 9 hari sebelum dan sesudah pengumuman pembagian dividen periode 2006-2008.

\section{HASIL DAN KESIMPULAN PENELITIAN}

Hasil pengujian regresi sederhana dari penelitian ini :

\section{Tabel 1 Regresi Kebijakan Dividen Terhadap Harga Saham}

Coefficients

\begin{tabular}{|c|c|c|c|c|c|c|}
\hline \multirow[b]{2}{*}{ Model } & & \multicolumn{2}{|c|}{$\begin{array}{c}\text { Unstandardized } \\
\text { Coefficients }\end{array}$} & \multirow{2}{*}{$\begin{array}{c}\begin{array}{c}\text { Standardized } \\
\text { Coefficients }\end{array} \\
\text { Beta }\end{array}$} & \multirow[b]{2}{*}{$\mathrm{t}$} & \multirow[b]{2}{*}{ Sig. } \\
\hline & & $\mathrm{B}$ & Std. Error & & & \\
\hline 1 & (Constant) & 288.354 & 415.425 & & .694 & .493 \\
\hline & DIVIDEN & 23.008 & 3.985 & .737 & 5.773 & .000 \\
\hline
\end{tabular}

a. Dependent Variable: SAHAM

Hasil analisis regresi menunjukkan bahwa pengaruh (koefisien regresi) kebijakan dividen terhadap harga saham sama dengan 23,01 dan mempunyai signifikansi ( $p$-value) sebesar 0,00. Berdasarkan hasil ini H0 ditolak pada taraf $\alpha=0,05$. Bukti analisis ini mengindikasikan bahwa variabel kebijakan dividen mempunyai pengaruh yang signifikan secara statistik terhadap variabel harga saham pada tingkat kepercayaan $95 \%$.

Berbeda halnya dengan koefisien regresi yang signifikan konstanta tidak memberikan pengaruh yang signifikan terhadap harga saham, Ini diperlihatkan dengan nilai signifikansi sama dengan 0,493, jauh lebih besar dari $\alpha=0,05$. Bukti tersebut mengindikasikan tidak adanya kontribusi pengaruh dari suatu konstanta dalam hubungan (pengaruh) kebijakan dividen terhadap harga saham. Dengan demikian, analisis dilanjutkan pada model pengaruh yang tidak melibatkan konstanta.

Tabel 2 Regresi Kebijakan Dividen Terhadap Harga Saham Tanpa Konstanta

Coefficients ${ }^{a, b}$

\begin{tabular}{|lc|r|r|r|r|r|}
\hline \multirow{2}{*}{ Model } & \multicolumn{2}{|c|}{$\begin{array}{c}\text { Unstandardized } \\
\text { Coefficients }\end{array}$} & \multicolumn{2}{|c|}{$\begin{array}{c}\text { Standardized } \\
\text { Coefficients }\end{array}$} & & \\
\cline { 2 - 5 } & \multicolumn{1}{|c|}{$\mathrm{B}$} & Std. Error & Beta & $\mathrm{t}$ & Sig. \\
\hline 1 & DIVIDEN & 25,167 & 2,469 &, 884 & 10,192 &, 000 \\
\hline
\end{tabular}

a. Dependent Variable: SAHAM

b. Linear Regression through the Origin

Hasil uji dengan konstanta menunjukkan bukti yang konsisten dengan hasil analisis dalam tabel 1 sebelumnya, bahwa variabel kebijakan dividen mempunyai pengaruh yang signifikan secara statistik terhadap variabel harga saham pada tingkat kepercayaan 95\%. tabel 
2 tersebut memperlihatkan perubahan harga koefisien regresi menjadi lebih besar, yaitu 25,17. Model hubungan kebijakan dividen terhadap harga saham berdasarkan hasil penaksiran parameter (koefisien regresi) dalam model, yaitu :

$$
\text { Harga Saham }=25,17 \text { Dividen }
$$

Uji koefisien determinasi :

Tabel 3 Koefisien Determinasi Kebijakan Dividen Terhadap Harga Saham

Model Summary

\begin{tabular}{|l|r|r|r|r|}
\hline Model & $\mathrm{R}$ & R Square & $\begin{array}{c}\text { Adjusted } \\
\text { R Square }\end{array}$ & $\begin{array}{c}\text { Std. Error of } \\
\text { the Es timate }\end{array}$ \\
\hline 1 &, $884^{\mathrm{b}}$ &, 782 &, 774 & 1409,81558 \\
\hline
\end{tabular}

b. Predictors : DIVIDEN

Uji koefesien determinasi menunjukkan bahwa kontribusi pengaruh (koefisien determinasi) kebijakan dividen terhadap harga saham sama dengan 0,782 atau 78,2\%. kontribusi atau peranan dari kebijakan dividen terhadap harga saham adalah relatif kuat. Sedangkan kontribusi pengaruh dari variabel lain di luar variabel kebijakan dividen adalah sebesar $1-78,2 \%=21,8 \%$.

Hasil uji signifikansi dari model $Y=25,17 X$ menggunakan statistik uji $\mathrm{F}$ dalam analisis ANOVA (Analysis of Variance) sebagai berikut:

Tabel 4 ANOVA (Pengujian Model)

ANOV A

\begin{tabular}{|c|c|c|c|c|c|c|}
\hline Model & & $\begin{array}{l}\text { Sum of } \\
\text { Squares }\end{array}$ & df & Mean Square & $\mathrm{F}$ & Sig. \\
\hline \multirow[t]{3}{*}{1} & Regression & $2 E+008$ & 1 & 206466555,8 & 103,878 &, $000^{\mathrm{a}}$ \\
\hline & Residual & 57639819 & 29 & 1987579,971 & & \\
\hline & Total & $3 E+008$ & 30 & & & \\
\hline
\end{tabular}

a. Predictors: DIVIDEN

Hasil uji ANOVA bahwa nilai signifikansi statistik F sama dengan $0,00<\alpha=0,05$. Hal ini membuktikan bahwa model $Y=25,17 X$ atau model pengaruh kebijakan dividen terhadap harga saham, secara statistik dapat diterima pada taraf kepercayaan $95 \%$

Hasil uji korelasi mengganakan pearson :

\section{Tabel 5 Analisis Korelasi}

\section{Correlations}

\begin{tabular}{|cl|r|r|}
\hline & & SAHAM & \multicolumn{1}{c|}{ DIVIDEN } \\
\hline SAHAM & Pearson Correlation & 1 & $.737^{\star *}$ \\
& Sig. (2-tailed) & & .000 \\
& $\mathrm{~N}$ & 30 & 30 \\
\hline DIVIDEN & Pearson Correlation & $.737^{\star *}$ & 1 \\
& Sig. (2-tailed) & .000 & \\
& $\mathrm{~N}$ & 30 & 30 \\
\hline
\end{tabular}

${ }^{* *}$. Correlation is significant at the 0.01 level (2-tailed). 
Hasil uji korelasi pearson menunjukkan nilai koefisien sama dengan 0,737 dan nilai signifikansi sama dengan 0,00. Hal ini membuktikan bahwa hubungan yang terjadi antara harga saham dan kebijakan dividen adalah signifikan dan termasuk ke dalam hubungan korelasi yang tinggi (high correlation).

Bukti tersebut konsisten dengan hasil analisis regresi sebelumnya, yang menjelaskan hubungan pengaruh secara linier variabel kebijakan dividen dengan harga saham. Nilai koefisien korelasi yang positif mengindikasikan hubungan yang saling menguatkan. Artinya, semakin besar dividen yang dibagikan maka akan meningkatkan harga saham perusahaan.

Uji Analisis beda rata-rata bertujuan untuk menguji apakah perbedaan yang ditunjukkan oleh data harga saham sebelum dan sesudah tanggal pengumuman dividen adalah benar-benar signifikan secara statistik atau tidak. Prosedur pengujian menggunakan statistik uji t.

\section{Tabel 6 Analisis Uji Beda t}

Paired Samples Test

\begin{tabular}{|c|c|c|c|c|c|c|c|}
\hline & & \multicolumn{3}{|c|}{ Paired Differences } & \multirow[b]{2}{*}{$\mathrm{t}$} & \multirow[b]{2}{*}{$\mathrm{df}$} & \multirow[b]{2}{*}{$\begin{array}{c}\text { Sig. } \\
\text { (2-tailed) }\end{array}$} \\
\hline & & Mean & $\begin{array}{c}\text { Std. } \\
\text { Deviation }\end{array}$ & $\begin{array}{c}\text { Std. Error } \\
\text { Mean }\end{array}$ & & & \\
\hline $\begin{array}{l}\text { Pair } \\
1\end{array}$ & $\begin{array}{l}\text { Harga saham sebelum } \\
\text { pengumuman dividen - } \\
\text { Harga saham s etelah } \\
\text { pengumuman dividen }\end{array}$ & $-137,50$ & 785,9964 & 248,55387 &,- 553 & 9 &, 594 \\
\hline
\end{tabular}

Hasil uji t menunjukan nilai statistik uji t sama dengan -0,553 dengan nilai signifkansi sebesar 0,594 yang jauh lebih besar dari taraf $\alpha=0,05$. Bukti ini mengindikasikan bahwa tidak terdapat perbedaan harga saham sebelum besar dividen diumumkan dan setelah dividen diumumkan dengan tingkat kepercayaan $95 \%$.

\section{PENUTUP}

Penelitian ini sudah selesai, penelitian ini dilakukan untuk mencari pengaruh besarnya dividen terhadap harga saham pada perusahaan keuangan yang tergabung kedalam LQ - 45 yang terdaftar di Bursa Efek Indonesia (BEI).

\section{REFERENSI:}

Baker, Malcolm, and Jeffrey Wurgler, 2004a. A catering theory of dividends, Journal of Finance 59, 1125-1165.

Gitman, Lawrence J., 1994, Principles of Managerial Finance, Seventh Edition, Harper Collins College Publishers.

Miller, Merton. H., dan Franco H. Modigliani, 1961. Dividend policy, growth, and the valuation of share, Journal of Business 34, 411-433.

Naveli, Raymond P. 1989. Fundamentals of Managerial Finance. Cincinnati Ohio: South Western Publishing 
Weygandt, J.J., Donald E. Keiso, Paul D. Kimmel, (2002), Edisi 6, Accounting Principles, New York; John Wiley \& Sons. 
